\section{DIGITAL COMMONS \\ @ UNIVERSITY OF SOUTH FLORIDA}

\section{ABO: Interactive Journal for Women in the Arts, 1640-1830}

Volume 4

Issue 1 Volume 4.1 (Spring 2014)

Article 7

2014

\title{
Review of Paula Backscheider, Elizabeth Singer Rowe and the Development of the English Novel
}

Sarah H. Prescott

Aberystwyth University, scp@aber.ac.uk

Follow this and additional works at: https://digitalcommons.usf.edu/abo

Part of the Dramatic Literature, Criticism and Theory Commons, Educational Methods Commons, Feminist, Gender, and Sexuality Studies Commons, and the Literature in English, British Isles Commons

\section{Recommended Citation}

Prescott, Sarah H. (2014) "Review of Paula Backscheider, Elizabeth Singer Rowe and the Development of the English Novel," ABO: Interactive Journal for Women in the Arts, 1640-1830: Vol.4: Iss.1, Article 7. http://dx.doi.org/10.5038/2157-7129.4.1.7

Available at: https://digitalcommons.usf.edu/abo/vol4/iss1/7

This Reviews is brought to you for free and open access by Digital Commons @ University of South Florida. It has been accepted for inclusion in ABO: Interactive Journal for Women in the Arts, 1640-1830 by an authorized administrator of Digital Commons @ University of South Florida. For more information, please contact digitalcommons@usf.edu. 


\section{Review of Paula Backscheider, Elizabeth Singer Rowe and the Development of the English Novel}

\section{Keywords}

Paula Backscheider, Elizabeth Singer Rowe, English Novel

\section{Creative Commons License}

\section{(c) $($ ) $\odot$}

This work is licensed under a Creative Commons Attribution-No Derivative Works 3.0 License. 
Paula R. Backscheider. Elizabeth Singer Rowe and the Development of the English Novel. Baltimore: Johns Hopkins UP, 2013. 303pp. Index. ISBN: 978-4214-0842-2.

\author{
Reviewed by Sarah Prescott \\ Aberystwyth University
}

Eighteenth-century women writers have characteristically been seen as marginal to the literary culture they inhabited and also to the subsequent literary histories which create the canonical writers of the present and future. Although Elizabeth Singer Rowe has, until recently, suffered from comparative neglect in accounts of women's literary history, quite the opposite was true in the eighteenth century itself. As Paula Backscheider points out in her fascinating revisionist study, Rowe was one of the most read, most well-known and most influential writers of her day. In statistical terms her publication record is in itself extraordinary, and it was her prose fiction, not her poetry, which was the bedrock of her widespread popularity. As in the joint publication of Defoe's Robinson Crusoe with Farther Adventures, Rowe's epistolary fiction Friendship in Death in Twenty Letters from the Dead to the Living was most frequently published as a single volume which included Letters Moral and Entertaining, in Prose and Verse, in Three Parts (first collected together in 1734). The following summary gives an insight into her amazing popularity:

In comparison to the seven editions of Rowe's text in the 1730s, there were three of Robinson Crusoe with Farther Adventures . . . . In the 1740s, there were three editions of Robinson Crusoe/Farther Adventures and six of Rowe's; in the 1750s, four of $R C / F A$, five of Richardson's Clarissa, and nine of hers; but in the 1760s, four of $R C / F A$, three of Clarissa, and an astonishing fourteen of hers. By 1825, there had been at least seventy-nine editions of Rowe's Letters, and by 1840, eighty-nine. (1-2)

The meticulous compilation of these figures gives the reader a context for the revisionary account of Rowe that is to follow. Backscheider takes the contemporary popularity of Rowe's fiction as her starting point to explore the cultural resonance of Rowe's status for literary culture in general: "As text, she was not a reified object but an active signifying practice, a cultural performer located in history, influencing the future, and negotiating personhood" (4).

What is so necessary and welcome about this study is that Backscheider does much more than simply 'rediscover' Rowe as a 'woman writer', although there is a wealth of new information here about Rowe and her literary career, including the discovery of some fascinating portraits of the writer. Rowe emerges as a pivotal figure of unique importance not only for understanding the development of the novel but also for the "structures of feeling" which drove eighteenth-century life and culture: conceptualisations of the self, a developing feminist consciousness, connections to landscape and place, the importance of letters and the representation of (female) happiness as steadfast independence and self-sufficiency, all of which, Backscheider argues, Rowe and her 'lifestyle' as a writer and a person exemplified and embodied. Certain aspects of the book are especially useful for thinking not only about Rowe but also about the broader implications of her significance as a 'pivotal' figure for the novel and eighteenth-century culture. For example, Backscheider makes the striking point that far from being staid and conservative or pious, Rowe was, in fact, a highly experimental writer who was often innovative and audacious in her writing. Such an approach presents a major re-evaluation of Rowe as a literary figure. In relation to conventional views of Rowe's poetry, Backscheider writes: "Critics have described it as if it were largely homogenous - 
that is, narrowly religious. However, it is more accurate to describe it as highly, even wildly, experimental in both content and form" (128). This insight is applied not only to the way in which her poetry and fiction intersect (an often overlooked aspect of Rowe's work and a unique aspect of Backscheider's approach) but also to how the experiments with narrative in the poetry inform her confident and adept handling of a variety of forms and genre in her epistolary fiction. Looking again at and expanding our sense of Rowe's use of genre partly explains why she was so culturally resonant as a writer and a figure. Backscheider's emphasis on the significance for the early novel of patchwork narratives, fairy tales, apparition literature, and letters places Rowe's fiction within an interpretative framework that acknowledges her innovation but which also places her in a sequence of influences. For example, by looking at the "Fairy Way of Writing" in Chapter Two, Backscheider makes the following suggestive connection between amatory fiction and the fairy tale: "Amatory fiction sets up situations in which the powerless must outwit established authority, but the conclusions tend to prove that the women are, indeed, largely powerless. In contrast, in fairy tales the powerless escape or triumph over authority, as children, the poor, and the scorned do in the New Testament" (103).

The repositioning of the powerless and thus the redefinition of women's sense of self is focused on in Chapter One, "Positioning Rowe's Fiction". The emphasis here is on Rowe's use of alternative plots which develop out of preoccupations in fiction generally (especially amatory fiction) with marriage, courtship, and female status and happiness (what we now call 'well-being'). As Backscheider notes, "Rowe writes about all of these things in revisionary and influential ways" (57). One example is the use of "the threesome" (in the story of Melinda in Letters 2) where Rowe fashions an alternative to the heterosexual marriage plot to include female friendship, the idea of autonomous existence, and, perhaps more strikingly, the possibility that marriage and an intellectual life might fruitfully co-exist. In relation to the above, Backscheider writes: "As Rowe's leading women characters seek a satisfying life, the guidance of reason plays an unusually prominent part" (58). Rowe's conceptualisation of women's sense of self and her foregrounding of a rational quest for self-sufficiency (with Rowe herself as the epitome) was a major influence on the Bluestockings later in the century and the model of intellectual femininity they represented. Rowe is thus a 'pivot' between amatory and later fiction and writing by women in that what she accomplished in her fiction was a movement from "the somatic terrain of the emotions" to "the space of the conceptual self" (123). Backscheider makes the convincing point that it is this combination of amatory rhetoric and a focus on the rational self which defines Rowe's version of "amatory pastoral". Furthermore, the suggestion that Rowe's particular brand of amatory pastoral is a key influence on the novel forces yet another radical reassessment of Rowe's fiction and its importance.

Elizabeth Singer Rowe and the Development of the English Novel is a study packed with original insights and observations which are carefully formulated and elegantly expressed. Although the focus is on Rowe, Backscheider's book also offers a range of innovative interpretative frameworks for re-thinking eighteenth-century literary culture and especially women's participation in it. One example of such a framework which Rowe's example opens up is women writers' relationship to geographical location. Central to Rowe's 'pious' image as 'the poetess of Frome' is the sense that Frome in Somerset was a rural retreat from the world, a kind of living death which could be seen to parallel the scenarios in her most popular work, Friendship in Death. In another example of the way in which this book throws open a further set of questions and routes for thought and investigation, geographical location is seen by Backscheider to determine women's 'control of the self'. As Backscheider states: 
"Women's increasing demand to have, if not choice, then the power to decline a would-be husband has been frequently studied, but where a woman was allowed to live is also a fascinating and richly symbolic subject" (158). In her fictional treatment of place and female friendship, what might be termed the 'spatial imagination' of novelistic discourse, Rowe is, yet again argues Backscheider, an innovator and a pivotal figure: "Part of Rowe's domesticating of the novel is unobtrusively suggesting that the almost unimaginably spacious country-house landscapes and gentry farms somehow can be shaded into tidy entrances to homes and middle-class contemplative spaces" (158). This multifaceted statement encapsulates the originality and style of this important and thought-provoking study. Backscheider's achievement in this book is not only in the demonstration of why Rowe was and continues to be an important writer, but also in the production of an original account of the novel and the various contexts which produced it. Overall, then, this is a richly suggestive and innovative book which succeeds in addressing both sides of its title - Elizabeth Singer Rowe - and - the Development of the English Novel and in so doing should spark new interest in the history of women's writing and the development of prose fiction in the eighteenth century. 